\title{
Estimated hospitalizations attributed to norovirus and rotavirus infection in Canada, 2006-2010
}

\author{
V. K. MORTON ${ }^{1,2 *}$, M. K. THOMAS ${ }^{1}$ AND S. A. McEWEN ${ }^{2}$ \\ ${ }^{1}$ Centre for Foodborne, Environmental and Zoonotic Infectious Diseases, Public Health Agency of Canada, \\ Guelph, Ontario Canada \\ ${ }^{2}$ University of Guelph, Department of Population Medicine, Guelph, Ontario Canada
}

Received 1 December 2014; Final revision 23 February 2015; Accepted 23 March 2015; first published online 20 May 2015

\section{SUMMARY}

Enteric viruses including norovirus and rotavirus are leading causes of gastroenteritis in Canada. However, only a small number of clinical cases are actually tested for these pathogens leading to systematic underestimation of attributed hospitalizations in administrative databases. The objective of this analysis was to estimate the number of hospitalizations due to norovirus and rotavirus in Canada. Hospitalization records for acute gastroenteritis-associated discharges at all acute-care hospitals in Canada between 2006 and 2011 were analysed. Cause-unspecified gastroenteritis hospitalizations were modelled using age-specific negative binomial models with cause-specified gastroenteritis admissions as predictors. The coefficients from the models were used to estimate the number of norovirus and rotavirus admissions. The total annual hospitalizations for rotavirus were estimated to be between 4500 and 10000 . Total annual hospitalizations for norovirus were estimated to be between 4000 and 11000 . The mean total annual cost associated with these hospitalizations was estimated to be at least $\$ 16$ million for rotavirus and \$21 million for norovirus (all figures in Canadian dollars). This study is the first comprehensive analysis of norovirus and rotavirus hospitalizations in Canada. These estimates provide a more complete assessment of the burden and economic costs of these pathogens to the Canadian healthcare system.

Key words: Norwalk agent and related viruses, rotavirus.

\section{INTRODUCTION}

Enteric illness is an important cause of morbidity and mortality worldwide [1]. In Canada, norovirus and rotavirus are two of the leading causes of acute gastroenteritis (AGE). Recent estimates indicate that about 3.4 million norovirus and 850000 rotavirus cases occur annually [2]. Although these illnesses are common, cases are rarely confirmed through laboratory

\footnotetext{
* Author for correspondence: Ms. V. K. Morton, 120-255 Woodlawn Road W, Guelph, Ontario N1H 8J1, Canada. (Email: Vanessa.Morton@phac-aspc.gc.ca)
}

testing because diagnosis does not change case management $[3,4]$. As a result of this limited testing, the incidence of these viruses tends to be systematically underrepresented in surveillance databases, including hospital records. In the absence of reliable information concerning hospitalizations it is difficult to assess their burden on the healthcare system, and to evaluate the potential costs and benefits of alternative public health policies.

Both norovirus and rotavirus are enteric viruses that can cause AGE; however, infections caused by these agents exhibit different epidemiological characteristics. Norovirus typically causes mild, self-limiting

This is an Open Access article, distributed under the terms of the Creative Commons Attribution licence (http://creativecommons.org/licenses/by/3.0/), which permits unrestricted re-use, distribution, and reproduction in any medium, provided the original work is properly cited. 
gastroenteritis in individuals of all ages and is most prevalent in the winter months. The virus is infectious at very low doses and is extremely stable in the environment, spreading easily from person to person [5]. Outbreaks occur frequently in closed settings such as schools, hospitals, long-term care facilities and cruise ships [6-9]. Although the virus can infect individuals of all ages, the impacts of infection tend to be greater in the elderly and individuals with underlying health conditions who are more likely to develop complications, and require hospitalization $[10,11]$.

Rotavirus infections occur in individuals of all ages, but illness in adults tends to be mild or asymptomatic [12]. Severe illness is most common in young children aged $<5$ years and can result in dehydration requiring medical attention or hospitalization [13]. Rotavirus infections are extremely common worldwide; with about $95 \%$ of children contracting the illness by age 5 years, and as a result the burden of this illness on the healthcare system is substantial, in both developed and developing countries [14]. To lessen this burden, two vaccines have recently been developed for rotavirus. These vaccines have been shown to significantly decrease hospitalization rates for young children $[15,16]$.

A recent study used indirect attribution from regression modelling techniques to estimate the incidence of norovirus and rotavirus hospitalization in the United States [17]. Similar to Canada, testing for enteric viruses is limited in the United States and many resulting hospitalizations are not laboratoryconfirmed, therefore these cases are classified as unspecified AGE since the causative agent is unknown. By examining hospitalization records attributed to AGE, Lopman et al. [17], were able to attribute portions of unspecified AGE hospitalizations to these viruses and were able to estimate the total number of hospitalizations and costs attributed to each virus.

The objective of the present study was to apply similar methods to examine Canadian hospital administration records and develop Canadian-specific estimates of hospitalization rates, and the associated costs for norovirus and rotavirus infection in different age groups [17].

\section{METHODS}

\section{Data sources}

Hospitalization data were obtained from the Hospital Morbidity Database maintained by the Canadian
Institute for Health Information (CIHI-HMDB) [18]. This database captures administrative, clinical and demographic information on all patient discharges from all acute-care hospitals across Canada. Clinical diagnoses are recorded using the International Statistical Classification of Diseases and Related Health Problems Tenth Revision, Canada (ICD-10-CA) coding standards. Up to 35 diagnoses are recorded in each patient discharge record. The first diagnosis, also known as the most responsible diagnosis, records the diagnosis most responsible for the patient's stay in the hospital. Remaining diagnoses are given a diagnosis type, including pre-admission comorbidity, post-admission comorbidity or secondary diagnosis.

CIHI-HMDB records with an admission date between 1 April 2006 and 31 March 2011 and at least one AGE diagnosis code (Table 1) within the first 16 diagnosis code positions were extracted. Entries were categorized using a hierarchy of specificity with specified pathogens' codes given priority over causeunspecified codes. Records with a specific pathogen code (e.g. C. difficile) and a cause-unspecified gastroenteritis code were categorized based on the pathogen code. Entries with more than one AGE category of pathogen code (e.g. C. difficile and viral AGE code) were excluded from analysis, as they could not be categorized.

Descriptive statistics were used to describe discharges by pathogen category. Death rates were calculated based on the discharge disposition recorded (i.e. status of patient at time of discharge). Incidence rates were calculated based on, age-stratified population estimates for Canada (2006-2010) obtained from Statistics Canada [19].

Reports of laboratory-confirmed clinical cases of enteric viruses from 2006 to 2011 were obtained from the National Enteric Surveillance Program (NESP) [20]. The NESP collects weekly counts of enteric pathogens from all 10 central provincial public health laboratories across Canada. This provided an independent dataset with which to compare the estimates developed.

\section{Statistical analysis}

The number of norovirus- and rotavirus-associated hospitalizations were estimated using an approach presented by Lopman et al. [17]. This approach assumes that a proportion of cause-unspecified gastroenteritis (unspecified gastroenteritis and unspecified 
Table 1. Descriptive statistics and associated diagnostic codes for acute gastroenteritis discharges, 2006-2011 CIHI-HMDB*

\begin{tabular}{|c|c|c|c|c|c|c|c|}
\hline Cause & ICD-10 codes & $\begin{array}{l}\text { No. of } \\
\text { patients }\end{array}$ & $\begin{array}{l}\text { Median } \\
\text { age }(y r)\end{array}$ & $\begin{array}{l}\text { Median length } \\
\text { of stay (days) }\end{array}$ & $\begin{array}{l}\% \\
\text { Males }\end{array}$ & $\begin{array}{l}\% \\
\text { Deaths } \dagger\end{array}$ & $\begin{array}{l}\% \\
\text { Post-admission } \downarrow\end{array}$ \\
\hline Bacteria & $\mathrm{A} 00-\mathrm{A} 04.6, \mathrm{~A} 04.8-\mathrm{A} 05.9$ & 13712 & 51 & 4 & 49 & $2 \cdot 9$ & $4 \cdot 9$ \\
\hline $\begin{array}{l}\text { Clostridium } \\
\text { difficile }\end{array}$ & A04.7 & 83606 & 76 & 17 & 44 & $17 \cdot 5$ & $39 \cdot 7$ \\
\hline Parasite & A06-A06.2, A06.9-A07.9 & 1017 & 42 & 5 & 56 & $3 \cdot 1$ & $3 \cdot 3$ \\
\hline Rotavirus & A08.0 & 8976 & 1 & 2 & 54 & $0 \cdot 2$ & $6 \cdot 1$ \\
\hline Norovirus & A08.1 & 3264 & 77 & 11 & 42 & $7 \cdot 3$ & $46 \cdot 2$ \\
\hline Adenovirus & A08.2 & 635 & 1 & 3 & 60 & $2 \cdot 1$ & $10 \cdot 1$ \\
\hline Other virus & A08.3 & 2906 & 4 & 2 & 49 & $1 \cdot 7$ & $9 \cdot 5$ \\
\hline $\begin{array}{l}\text { Unspecified } \\
\text { virus }\end{array}$ & A08.4 & 46099 & 31 & 2 & 43 & $1 \cdot 0$ & $5 \cdot 6$ \\
\hline $\begin{array}{l}\text { Unspecified } \\
\text { gastroenteritis }\end{array}$ & A09-A09.9, K52.8-K52.9 & 240137 & 61 & 4 & 41 & $3 \cdot 7$ & $12 \cdot 9$ \\
\hline
\end{tabular}

* Canadian Institutes of Health Information - Hospital Morbidity Database.

$\dagger$ Percent of total discharges where the discharge disposition was listed as deceased.

$\$$ Percent of total discharges where diagnostic code of interest was classified as developing post-admission to hospital.

virus) hospitalizations are due to norovirus or rotavirus infections. In order to estimate the number of hospitalizations, models were built to account for hospitalizations that likely occurred due to bacterial pathogens (including $C$. difficile), viral and parasitic pathogens among the cause-unspecified hospitalizations. Specifically, the numbers of monthly causeunspecified diagnoses were modelled as a function of the monthly admissions associated with bacterial, viral, parasitic and $C$. difficile infections using the following negative binomial generalized linear model:

$$
\begin{aligned}
E\left(\mathrm{CU}_{x y}\right)= & \alpha+\beta_{1} \times \text { bact }_{x y}+\beta_{2} \times \operatorname{Cdiff}_{x y}+\beta_{3} \\
& \times \operatorname{para}_{x y}+\beta_{4} \times \text { noro }_{x y}+\beta_{5} \times \operatorname{rota}_{x y} \\
& +\beta_{6} \times \text { time }_{y},
\end{aligned}
$$

where $x$ represents the age group and $y$ the month. Hospitalization records were modelled based on the month of admission as this was thought to be more reflective of the seasonal pattern of infection compared to month of discharge. A time parameter was also included in the model to account for any underlying hospitalization trends over time. Models were fit using an identity link to ensure that regression coefficients were on a linear scale. A separate model was generated for each of five age groups $(0-4,5-17$, $18-64,65-84, \geqslant 85$ years). Coefficient values from the models for norovirus and rotavirus were multiplied by the monthly hospitalization count for norovirus and rotavirus, respectively, to estimate the number of cause-unspecified cases attributed to the two viruses. Confidence intervals around the coefficients were similarly used to develop $95 \%$ confidence intervals around the estimates. To determine the overall number of hospitalizations, estimates from the model were combined with the coded norovirus and rotavirus entries from CIHI-HMDB.

Analysis was conducted using SAS version 9.3 (SAS Institute Inc., USA) and Excel 2010 (Microsoft Corporation, USA).

\section{Hospitalization costs}

Mean annual hospitalization costs by age group for discharges with most responsible diagnostic code of norovirus (A08.1) or rotavirus (A08.0) were obtained for 2006 to 2008 [21]. These costs are calculated by attributing a proportion of the total hospital expenditure to each hospitalization stay. As a result, these values include all expenses associated with a hospital stay such as administrative costs, drugs and medical supplies, staff salaries and hospital maintenance. These age-specific costs were modelled using a triangular distribution where the minimum, most likely and maximum values were the lowest, mean and highest annual cost per case during this time-frame; and multiplied by a cumulative distribution of age-specific total annual admissions for each of norovirus and rotavirus. This method helps to account for uncertainty and variability of the inputs. Estimates were generated using Monte Carlo simulations (10000 iterations) with@Risk software (Palisade Corporation, USA). 
All dollar figures are reported in Canadian currency and adjusted to 2008 values to account for inflation using the Bank of Canada Inflation Calculator (http://www.bankofcanada.ca/rates/related/inflationcalculator/).

\section{RESULTS}

During the study period 401364 discharges were identified with at least one diagnostic code of interest within the first 16 diagnoses; however, $1051(0 \cdot 2 \%)$ of these discharges had more than one category of diagnostic code of interest and were removed from the analysis. Discharges were categorized based on the type of causative agent (Table 1). Median age of infected patients ranged from 1 year (rotavirus and adenovirus) to 76-77 years ( $C$. difficile and norovirus). Measures of severity, such as length of stay and death rate, were highest for $C$. difficile and norovirus. The percent of post-admission diagnoses was also highest for norovirus $(46 \%)$, a measure of nosocomial transmission. The percent of norovirus infections diagnosed post-admission ranged considerably by age, from $17 \%$ in those aged $0-17$ years to $52-54 \%$ in those aged $\geqslant 65$ years. Similarly for rotavirus infection, about $5 \%$ of cases were nosocomial in individuals aged $0-17$ years, while $27-34 \%$ of cases in individuals aged $\geqslant 65$ years were classified as postadmission conditions (data not shown).

In total, there was a mean annual rate of 24 hospital discharges due to AGE illnesses per 10000 in Canada (Table 2). The percentages of discharges specifically attributed to norovirus and rotavirus infection were low at $1 \%$ and $2 \%$, respectively. However, the majority $(60 \%)$ of AGE hospitalizations were due to unspecified agents, with an additional $11 \%$ attributed to unspecified viruses. The monthly distribution of cause-unspecified gastroenteritis shows a seasonal pattern (Fig. 1). In the older age groups ( $>18$ years) the number of admissions peaks around January each year, which is consistent with the known seasonal patterns of norovirus in Canada [22]. In the youngest age group ( $0-4$ years), a small increase occurs in January with a considerably larger peak around April, consistent with the seasonality of rotavirus infection in Canada [23].

Overall, the model estimated that norovirus and rotavirus infections account for about $11 \%$ and $10 \%$ of the total AGE cause-unspecified hospitalizations, respectively. Model predictions combined with coded hospitalizations resulted in total annual hospitalizations of between 4097 and 11077 for norovirus infection and 4540-9931 for rotavirus infection (Tables 3 and 4). The monthly distribution pattern of the estimates corresponded closely with the seasonal trend reported in NESP for norovirus and rotavirus, respectively (Figs 2 and 3). The number of isolates reported through this programme was substantially underestimated compared to the estimated burden of illness. However, the number of laboratories reporting through NESP is consistent, therefore the seasonal trend in reported cases is reflective of the true seasonal trends [24]. Comparison of the monthly estimates with independent data from NESP provided additional evidence that the hospitalization estimates obtained from modelling were reflective of observed trends in Canada.

Mean annual costs associated with norovirus hospitalizations in Canada were estimated at \$20.8 million [90\% credible interval (CrI) \$14.9-\$28.9 million] (Table 5). A majority $(69 \%)$ of the costs were associated with hospitalizations in individuals aged $\geqslant 65$ years. The hospitalization costs were slightly lower for rotavirus infections, with a mean annual cost of \$16.1 million (90\% CrI \$11.0-\$22.3 million). Most of these costs $(73 \%)$ were due to hospitalizations in the $<5$ years age group.

\section{DISCUSSION}

We estimate that on average 7000 and 7500 hospitalizations annually in Canada involved norovirus and rotavirus infection, respectively. These estimates represent a substantial increase compared to the number of hospitalizations with norovirus- or rotavirusspecific codes in hospital records; four times greater for rotavirus-related and 11 times greater for norovirus-related reported hospitalizations accounted for in hospital records. Based on these figures, we estimate that norovirus and rotavirus infections combined cost the Canadian healthcare system up to $\$ 37$ million annually in direct hospital costs. Hospital records also indicate that a substantial proportion of norovirus cases are nosocomial.

In order to develop these estimates, modelling techniques were employed, based on the assumption that proportions of unspecified gastroenteritis hospitalizations are due to infection with norovirus and rotavirus. The results obtained are consistent with the known epidemiology of these enteric infections. For instance the estimated monthly seasonality corresponds well with the known seasonal distribution of 
Table 2. Mean annual total and incidence rate of gastroenteritis hospitalizations by pathogen category for 20062011, CIHI-HMDB*

\begin{tabular}{|c|c|c|c|c|c|c|}
\hline \multirow[b]{2}{*}{ Cause } & \multicolumn{3}{|c|}{ Most responsible diagnosis } & \multicolumn{3}{|c|}{ Other diagnosis (2-16 diagnostic codes) } \\
\hline & $\begin{array}{l}\text { Mean annual } \\
\text { total }\end{array}$ & $\%$ & $\begin{array}{l}\text { Mean annual incidence } \\
\text { rate (per } 10000)\end{array}$ & $\begin{array}{l}\text { Mean annual } \\
\text { total }\end{array}$ & $\%$ & $\begin{array}{l}\text { Mean annual incidence } \\
\text { rate (per } 10000 \text { ) }\end{array}$ \\
\hline Bacteria & 1884 & 5 & $0 \cdot 56$ & 2742 & 3 & $0 \cdot 81$ \\
\hline Clostridium difficile & 5568 & 14 & $1 \cdot 65$ & 16940 & 21 & $5 \cdot 04$ \\
\hline Parasite & 80 & 0 & $0 \cdot 02$ & 202 & 0 & $0 \cdot 06$ \\
\hline Rotavirus & 1456 & 4 & $0 \cdot 43$ & 1780 & 2 & $0 \cdot 53$ \\
\hline Norovirus & 184 & 0 & $0 \cdot 05$ & 587 & 1 & $0 \cdot 17$ \\
\hline Adenovirus & 87 & 0 & $0 \cdot 03$ & 130 & 0 & $0 \cdot 04$ \\
\hline Other virus & 369 & 1 & $0 \cdot 11$ & 562 & 1 & $0 \cdot 17$ \\
\hline Unspecified virus & 6274 & 16 & $1 \cdot 87$ & 8986 & 11 & $2 \cdot 67$ \\
\hline $\begin{array}{l}\text { Unspecified } \\
\text { gastroenteritis }\end{array}$ & 23135 & 59 & $6 \cdot 88$ & 47826 & 60 & $14 \cdot 22$ \\
\hline Total & 39035 & & $11 \cdot 61$ & 79754 & & $23 \cdot 71$ \\
\hline
\end{tabular}

* Canadian Institutes of Health Information - Hospital Morbidity Database.

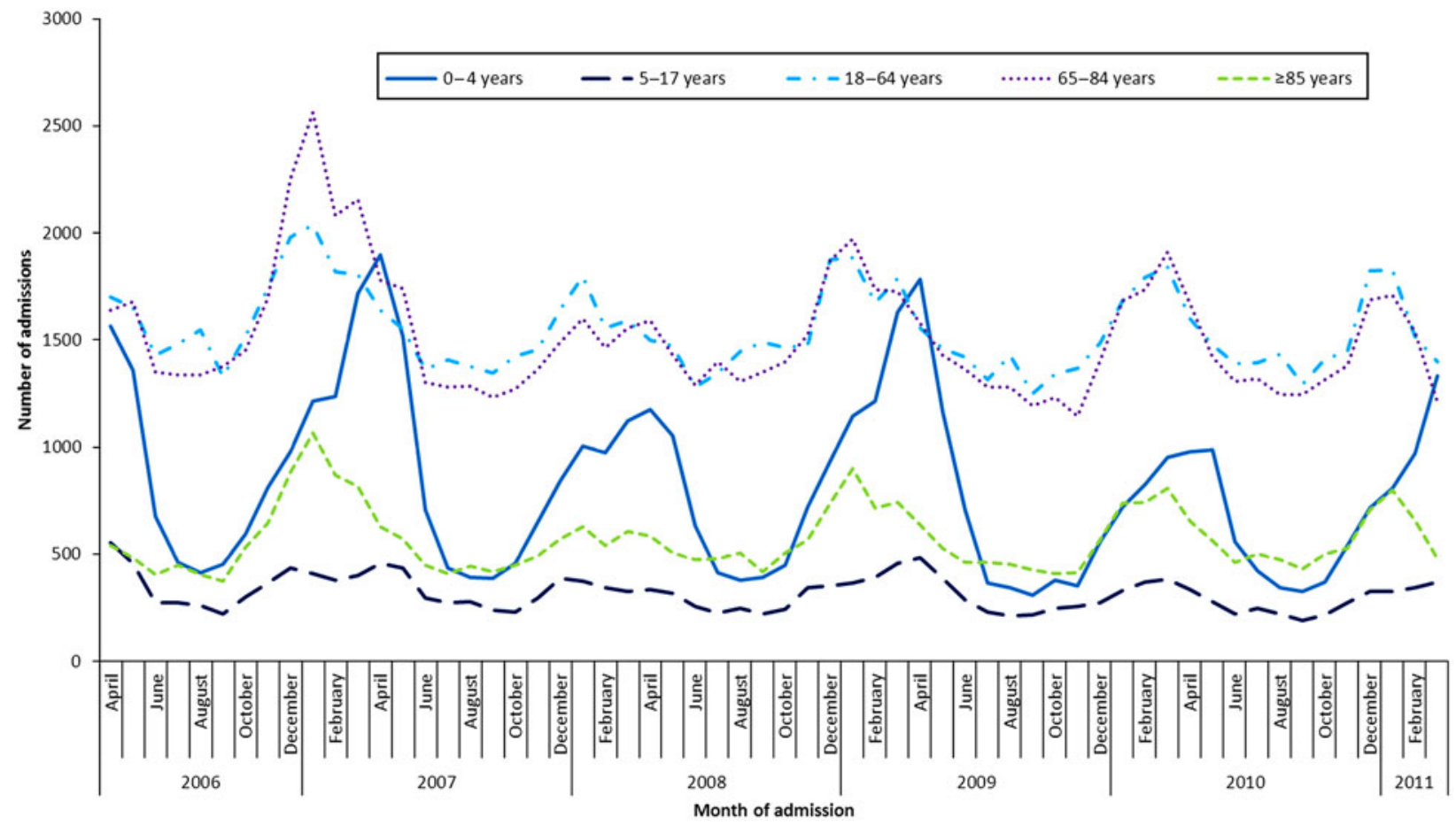

Fig. 1. Seasonal pattern of cause-unspecified gastroenteritis hospitalizations, month and year of admission, by age group, 2006-2011, Canadian Institutes of Health Information - Hospital Morbidity Database.

infection with each virus: norovirus peaking in early winter and rotavirus a few months later in early spring $[22,23]$. Moreover, the age distribution of the estimated hospitalizations is consistent with known infections due to these agents; the majority of rotavirus-associated hospitalizations were in the $<5$ years age group, while norovirus hospitalizations are more common in the elderly $[10,25]$.
The study by Lopman et al. [17] which served as a model for this work, calculated comparable annual hospitalization rates for both viruses; 24/100 000 for norovirus and 29/100 000 for rotavirus compared to our estimates of 21/100 000 and 23/100 000, respectively. One other study from The Netherlands also estimated the overall burden of norovirus, and reported an estimated annual hospitalization rate of $12 / 100000$ in 
Table 3. Estimated (including known coded hospitalizations) norovirus-associated hospitalizations and incidence per 100000 people, by age group and year, $2006-2010$

\begin{tabular}{|c|c|c|c|c|c|c|c|c|c|c|c|c|}
\hline \multirow[b]{2}{*}{ Year } & \multicolumn{6}{|c|}{ Number of hospitalizations $(95 \% \mathrm{CI})$} & \multicolumn{6}{|c|}{ Incidence per 100000 persons $(95 \% \mathrm{CI})$} \\
\hline & $0-4 \mathrm{yr}$ & $5-17 \mathrm{yr}$ & $18-64 \mathrm{yr}$ & $65-84 \mathrm{yr}$ & $\geqslant 85 \mathrm{yr}$ & All ages & $0-4 \mathrm{yr}$ & $5-17 \mathrm{yr}$ & $18-64 \mathrm{yr}$ & $65-84 \mathrm{yr}$ & $\geqslant 85 \mathrm{yr}$ & All ages \\
\hline $2006 / 2007$ & $\begin{array}{l}1321 \\
(878-1765)\end{array}$ & $\begin{array}{l}157 \\
(24-290)\end{array}$ & $\begin{array}{l}3116 \\
(2421-3812)\end{array}$ & $\begin{array}{l}4102 \\
(3353-4852)\end{array}$ & $\begin{array}{l}2380 \\
(1967-2793)\end{array}$ & $\begin{array}{l}11077 \\
(8643-13512)\end{array}$ & $\begin{array}{l}95 \\
(63-127)\end{array}$ & $\begin{array}{l}1 \\
(0-1)\end{array}$ & $\begin{array}{l}59 \\
(46-73)\end{array}$ & $\begin{array}{l}107 \\
(88-127)\end{array}$ & $\begin{array}{l}446 \\
(368-523)\end{array}$ & $\begin{array}{l}34 \\
(26-41)\end{array}$ \\
\hline $2007 / 2008$ & $\begin{array}{l}1021 \\
(678-1364)\end{array}$ & $\begin{array}{l}140 \\
(22-259)\end{array}$ & $\begin{array}{l}966 \\
(750-1181)\end{array}$ & $\begin{array}{l}1097 \\
(897-1298)\end{array}$ & $\begin{array}{l}873 \\
(721-1024)\end{array}$ & $\begin{array}{l}4097 \\
(3068-5126)\end{array}$ & $\begin{array}{l}72 \\
(48-97)\end{array}$ & $\begin{array}{l}1 \\
(0-1)\end{array}$ & $\begin{array}{l}19 \\
(14-23)\end{array}$ & $\begin{array}{l}28 \\
(23-33)\end{array}$ & $\begin{array}{l}155 \\
(128-181)\end{array}$ & $\begin{array}{l}12 \\
(9-16)\end{array}$ \\
\hline $2008 / 2009$ & $\begin{array}{l}1321 \\
(878-1765)\end{array}$ & $\begin{array}{l}190 \\
(29-351)\end{array}$ & $\begin{array}{l}1975 \\
(1534-2416)\end{array}$ & $\begin{array}{l}1982 \\
(1620-2343)\end{array}$ & $\begin{array}{l}1067 \\
(882-1252)\end{array}$ & $\begin{array}{l}6535 \\
(4943-8127)\end{array}$ & $\begin{array}{l}92 \\
(61-123)\end{array}$ & $\begin{array}{l}1 \\
(0-2)\end{array}$ & $\begin{array}{l}39 \\
(30-47)\end{array}$ & $\begin{array}{l}50 \\
(41-59)\end{array}$ & $\begin{array}{l}179 \\
(148-210)\end{array}$ & $\begin{array}{l}20 \\
(15-24)\end{array}$ \\
\hline $2009 / 2010$ & $\begin{array}{l}1121 \\
(745-1498)\end{array}$ & $\begin{array}{l}165 \\
(25-305)\end{array}$ & $\begin{array}{l}1639 \\
(1273-2004)\end{array}$ & $\begin{array}{l}2203 \\
(1800-2605)\end{array}$ & $\begin{array}{l}1239 \\
(1024-1454)\end{array}$ & $\begin{array}{l}6366 \\
(4867-7865)\end{array}$ & $\begin{array}{l}76 \\
(51-102)\end{array}$ & $\begin{array}{l}1 \\
(0-1)\end{array}$ & $\begin{array}{l}32 \\
(25-39)\end{array}$ & $\begin{array}{l}54 \\
(44-64)\end{array}$ & $\begin{array}{l}198 \\
(163-232)\end{array}$ & $\begin{array}{l}19 \\
(14-23)\end{array}$ \\
\hline Mean & $\begin{array}{l}1196 \\
(795-1598)\end{array}$ & $\begin{array}{l}163 \\
(25-301)\end{array}$ & $\begin{array}{l}1924 \\
(1494-2353)\end{array}$ & $\begin{array}{l}2346 \\
(1917-2774)\end{array}$ & $\begin{array}{l}1390 \\
(1148-1631)\end{array}$ & $\begin{array}{l}7019 \\
(5380-8658)\end{array}$ & $\begin{array}{l}84 \\
(56-112)\end{array}$ & $\begin{array}{l}1 \\
(0-1)\end{array}$ & $\begin{array}{l}37 \\
(29-45)\end{array}$ & $\begin{array}{l}60 \\
(49-71)\end{array}$ & $\begin{array}{l}244 \\
(202-287)\end{array}$ & $\begin{array}{l}21 \\
(16-26)\end{array}$ \\
\hline
\end{tabular}

CI, Confidence interval.

Table 4. Estimated (including known coded hospitalizations) rotavirus-associated hospitalizations and incidence per 100000 people, by age group and year, $2006-2010$

\begin{tabular}{|c|c|c|c|c|c|c|c|c|c|c|c|c|}
\hline \multirow[b]{2}{*}{ Year } & \multicolumn{6}{|c|}{ Number of hospitalizations (95\% CI) } & \multicolumn{6}{|c|}{ Incidence per 100000 persons $(95 \% \mathrm{CI})$} \\
\hline & $0-4 \mathrm{yr}$ & $5-17 \mathrm{yr}$ & $18-64 \mathrm{yr}$ & $65-84 \mathrm{yr}$ & $\geqslant 85 \mathrm{yr}$ & All ages & $0-4 \mathrm{yr}$ & $5-17 \mathrm{yr}$ & $18-64$ yr & $65-84$ yr & $\geqslant 85 \mathrm{yr}$ & All ages \\
\hline $2006 / 2007$ & $\begin{array}{l}7525 \\
(7002-8047)\end{array}$ & $\begin{array}{l}930 \\
(695-1165)\end{array}$ & $\begin{array}{l}640 \\
(148-1132)\end{array}$ & $\begin{array}{l}674 \\
(317-1032)\end{array}$ & $\begin{array}{l}162 \\
(34-289)\end{array}$ & $\begin{array}{l}9931 \\
(8196-11666)\end{array}$ & $\begin{array}{l}542 \\
(504-579)\end{array}$ & $\begin{array}{l}4 \\
(3-5)\end{array}$ & $\begin{array}{l}12 \\
(3-22)\end{array}$ & $\begin{array}{l}18 \\
(8-27)\end{array}$ & $\begin{array}{l}30 \\
(6-54)\end{array}$ & $\begin{array}{l}30 \\
(25-36)\end{array}$ \\
\hline $2007 / 2008$ & $\begin{array}{l}4395 \\
(4089-4700)\end{array}$ & $\begin{array}{l}493 \\
(368-617)\end{array}$ & $\begin{array}{l}180 \\
(42-318)\end{array}$ & $\begin{array}{l}491 \\
(230-751)\end{array}$ & $\begin{array}{l}65 \\
(14-116)\end{array}$ & $\begin{array}{l}5622 \\
(4743-6502)\end{array}$ & $\begin{array}{l}312 \\
(290-333)\end{array}$ & $\begin{array}{l}2 \\
(2-3)\end{array}$ & $\begin{array}{l}3 \\
(1-6)\end{array}$ & $\begin{array}{l}13 \\
(6-19)\end{array}$ & $\begin{array}{l}11 \\
(2-20)\end{array}$ & $\begin{array}{l}17 \\
(14-20)\end{array}$ \\
\hline $2008 / 2009$ & $\begin{array}{l}7217 \\
(6716-7718)\end{array}$ & $\begin{array}{l}960 \\
(717-1203)\end{array}$ & $\begin{array}{l}400 \\
(93-707)\end{array}$ & $\begin{array}{l}981 \\
(461-1501)\end{array}$ & $\begin{array}{l}259 \\
(54-463)\end{array}$ & $\begin{array}{l}9816 \\
(8041-11592)\end{array}$ & $\begin{array}{l}501 \\
(466-536)\end{array}$ & $\begin{array}{l}4 \\
(3-5)\end{array}$ & $\begin{array}{l}8 \\
(2-14)\end{array}$ & $\begin{array}{l}25 \\
(12-38)\end{array}$ & $\begin{array}{l}43 \\
(9-78)\end{array}$ & $\begin{array}{l}29 \\
(24-35)\end{array}$ \\
\hline $2009 / 2010$ & $\begin{array}{l}3201 \\
(2979-3423)\end{array}$ & $\begin{array}{l}344 \\
(257-431)\end{array}$ & $\begin{array}{l}360 \\
(84-637)\end{array}$ & $\begin{array}{l}521 \\
(245-798)\end{array}$ & $\begin{array}{l}113 \\
(24-203)\end{array}$ & $\begin{array}{l}4540 \\
(3588-5491)\end{array}$ & $\begin{array}{l}217 \\
(202-232)\end{array}$ & $\begin{array}{l}2 \\
(1-2)\end{array}$ & $\begin{array}{l}7 \\
(2-13)\end{array}$ & $\begin{array}{l}13 \\
(6-19)\end{array}$ & $\begin{array}{l}18 \\
(4-32)\end{array}$ & $\begin{array}{l}13 \\
(11-16)\end{array}$ \\
\hline Mean & $\begin{array}{l}5584 \\
(5197-5972)\end{array}$ & $\begin{array}{l}682 \\
(509-854)\end{array}$ & $\begin{array}{l}395 \\
(92-698)\end{array}$ & $\begin{array}{l}667 \\
(313-1020)\end{array}$ & $\begin{array}{l}150 \\
(31-268)\end{array}$ & $\begin{array}{l}7477 \\
(6142-8813)\end{array}$ & $\begin{array}{l}393 \\
(366-420)\end{array}$ & $\begin{array}{l}3 \\
(2-4)\end{array}$ & $\begin{array}{l}8 \\
(2-13)\end{array}$ & $\begin{array}{l}17 \\
(8-26)\end{array}$ & $\begin{array}{l}26 \\
(5-46)\end{array}$ & $\begin{array}{l}23 \\
(19-27)\end{array}$ \\
\hline
\end{tabular}

CI, Confidence interval. 


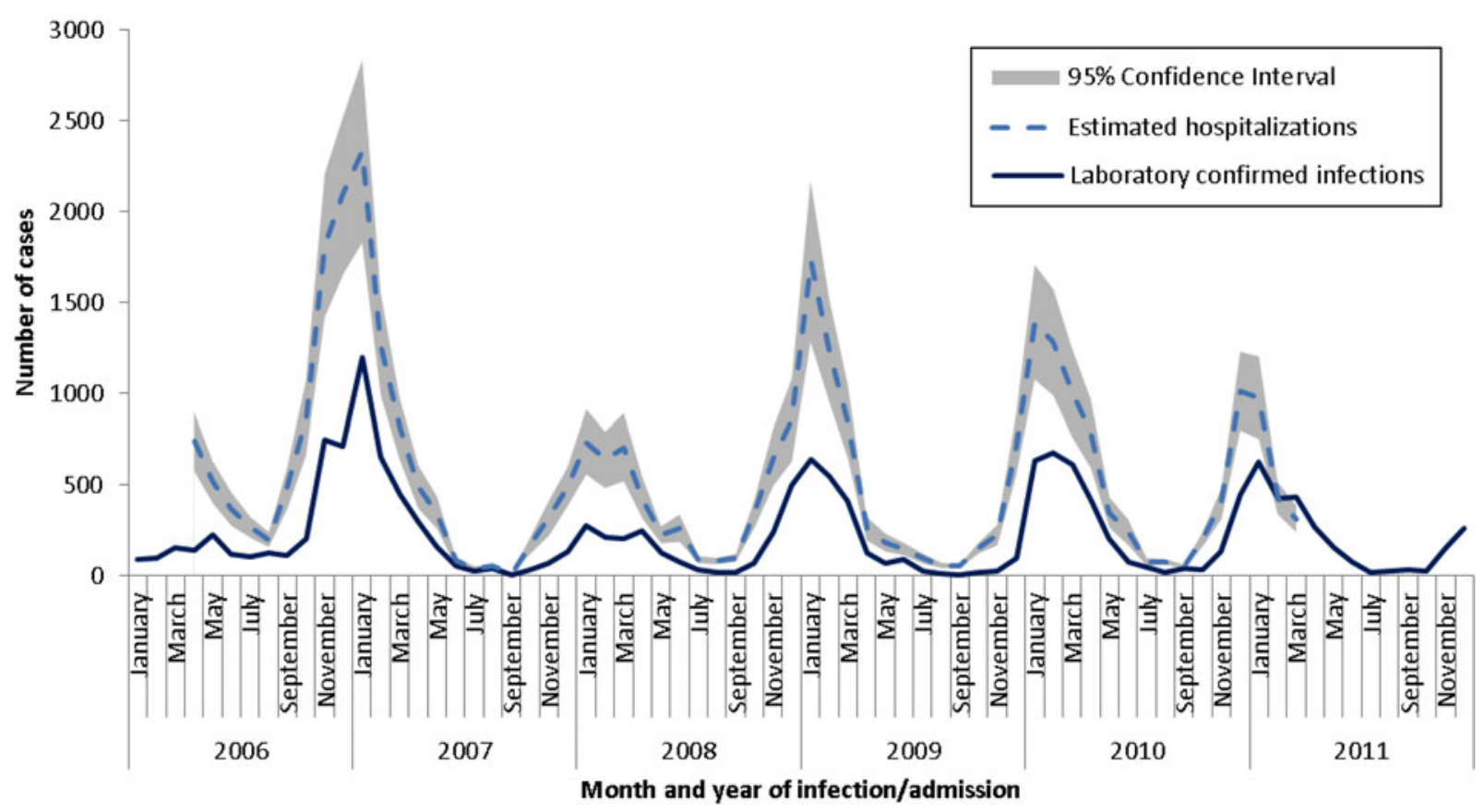

Fig. 2. Seasonal distribution of laboratory-confirmed norovirus infections reported to the National Enteric Surveillance Program (NESP) and estimated norovirus hospitalizations by month and year of admission, 2006-2011.

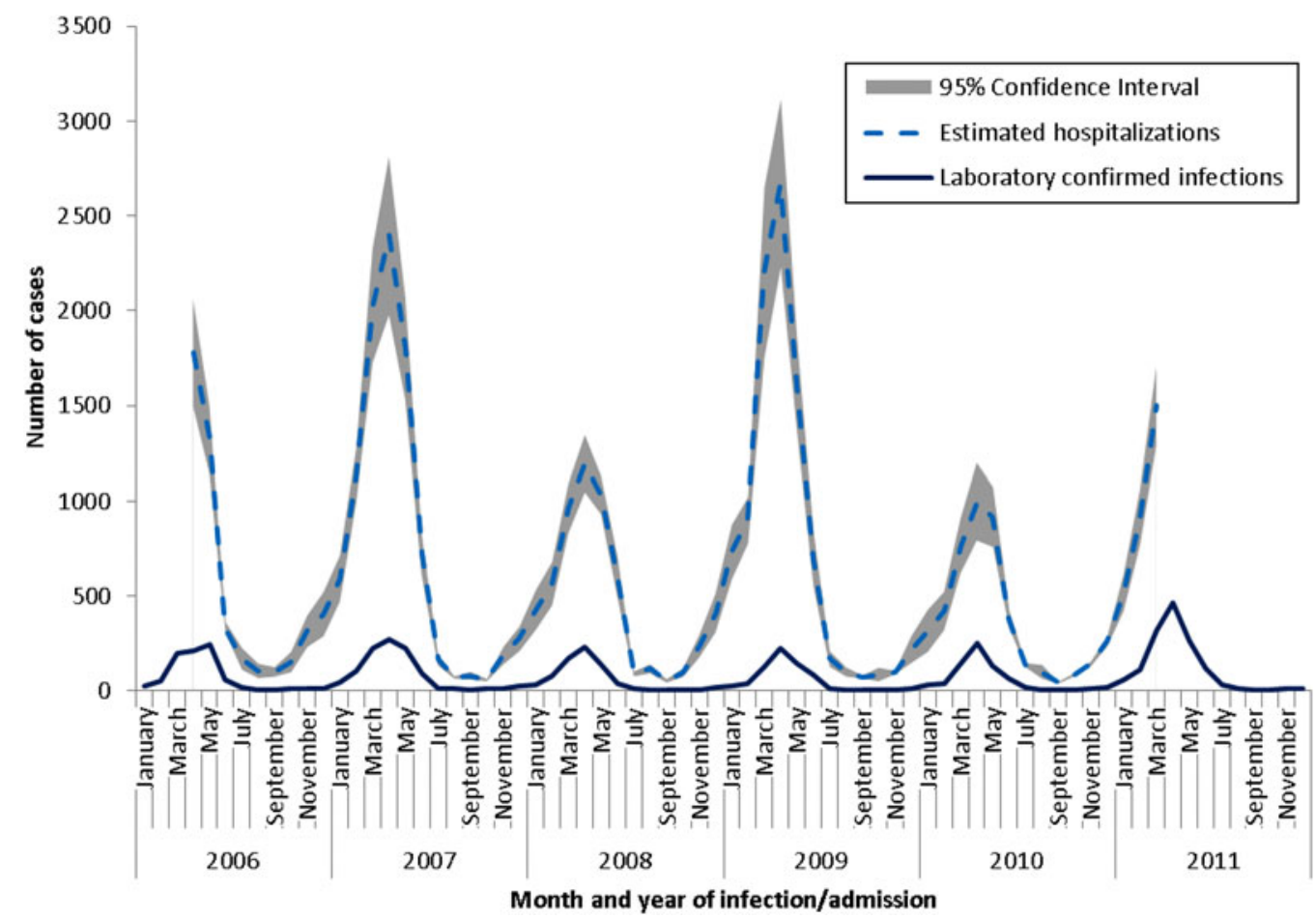

Fig. 3. Seasonal distribution of laboratory-confirmed rotavirus infections reported to the National Enteric Surveillance Program (NESP) and estimated rotavirus hospitalizations by month and year of admission, 2006-2011.

the general population [26]. This estimate was, however, limited to community-acquired cases. Our estimate is higher but if we consider that about $46 \%$ of norovirus are nosocomial, our estimate for community-acquired cases would be $11 / 100000$ which is consistent with the estimate from The Netherlands. 
Table 5. Estimated annual hospital costs associated with norovirus and rotavirus infection, by age group, and seasonal years 2006/2007-2009/2010

\begin{tabular}{|c|c|c|c|c|}
\hline \multirow[b]{2}{*}{$\begin{array}{l}\text { Age group } \\
(\mathrm{yr})\end{array}$} & \multicolumn{2}{|l|}{ Norovirus } & \multicolumn{2}{|l|}{ Rotavirus } \\
\hline & $\begin{array}{l}\text { Cost per hospitalization, } \\
\text { range }\end{array}$ & $\begin{array}{l}\text { Annual cost, mean }(90 \% \\
\text { CrI) }\end{array}$ & $\begin{array}{l}\text { Cost per hospitalization, } \\
\text { range }\end{array}$ & $\begin{array}{l}\text { Annual cost, mean }(90 \% \\
\text { CrI) }\end{array}$ \\
\hline $0-4$ & 2354-2959 & $\begin{array}{l}3002786 \\
(2515153-3611199)\end{array}$ & $2215-2409$ & $\begin{array}{l}11695509 \\
(7301687-17415599)\end{array}$ \\
\hline $5-17$ & $1021-1879$ & $\begin{array}{l}212572 \\
(161926-279306)\end{array}$ & $2118-2327$ & $\begin{array}{l}1358122 \\
(757824-2166385)\end{array}$ \\
\hline 18-64 & $1763-2070$ & $\begin{array}{l}3223461 \\
(1818970-15535059)\end{array}$ & $1536-2621$ & $\begin{array}{l}683532 \\
(325802-1214375)\end{array}$ \\
\hline $65-84$ & $3871-4940$ & $\begin{array}{l}8273017 \\
(4323058-1535059)\end{array}$ & $2635-3681$ & $\begin{array}{l}1808555 \\
(1336943-2762153)\end{array}$ \\
\hline$\geqslant 85$ & $4771-5485$ & $\begin{array}{l}6126561 \\
(4333677-10963642)\end{array}$ & $1586-7150$ & $\begin{array}{l}571448 \\
(215329-1191148)\end{array}$ \\
\hline Total & & $\begin{array}{l}20838397 \\
(14934994-28919793)\end{array}$ & & $\begin{array}{l}16117165 \\
(10987357-22325928)\end{array}$ \\
\hline
\end{tabular}

CrI, Credible interval.

All values are in Canadian dollars (adjusted to 2008 value).

Although few studies estimate the burden of norovirus hospitalization, numerous studies have been conducted to estimate the hospitalization rate for rotavirus infection in the $0-5$ years age group. For example, two Canadian studies reported annual hospitalization rates of 450/100 000 and 500-740/100 000 in children aged $<5$ years $[23,27]$ and these figures are higher than the range estimated by the present study (366-420/100 000). These previous Canadian studies both involved retrospective review of hospital records for multiple AGE codes, including unspecified AGE-associated codes, and used modelling techniques to attribute a proportion to rotavirus. Both of these previous studies examined hospital records solely from a small area of the province of Quebec and thus may not be representative of national trends in hospitalization rates. Moreover, they did not consider or control for norovirus infections in their estimates. These previous studies did demonstrate substantial year-to-year variations in rotavirus hospitalizations, a pattern also observed in our estimates. This variation has also been observed in the United States and may be partially explained by genetic variation in circulating strains of virus [28].

We also observed considerable annual variability in the estimated number of hospitalizations for norovirus infection, which is consistent with other studies. Circulating strains of norovirus are known to evolve, with new strains emerging every few years and causing increased numbers of illnesses [29]. For example, in 2006/2007 two new strains emerged in Canada and the rest of the world causing a substantial increase in the number of observed outbreaks of norovirus infection $[22,30]$.

Analysis of hospitalization records indicated that $46 \%$ of norovirus patients developed symptoms after admission to hospital. This finding is in line with the literature as a high number of outbreaks are known to occur in hospital settings [9]. However, this is the first report, to our knowledge, to quantify the rate of nosocomial transmission in Canadian hospitals. Nosocomial norovirus infection likely extends the hospital stays of many of these patients who are initially hospitalized for other conditions. The estimated rate of nosocomial transmission was, however, much lower for rotavirus at $6 \%$ in all age groups and only $5 \%$ in patients aged $<5$ years. This is likely an underestimate as previous studies that used active surveillance to identify cases found substantially higher nosocomial rates of $14-51 \%$ in the $<5$ years age group [31, 32].

There are potential limitations of this study. The regression models considered only norovirus or rotavirus infections and not a wide range of other enteric viruses known to cause gastroenteritis. For instance, enteric viruses such as sapovirus, astrovirus and adenovirus are increasingly recognized as potentially important contributors to enteric illness [33], 
and sapovirus and astrovirus infections also tend to increase in the winter months $[34,35]$. Therefore it is possible that proportions of the cause-unspecified discharges attributed to norovirus and rotavirus in our study are attributable to these other enteric viruses. Second, we assumed that a fixed multiplier could be applied to the number of coded hospitalizations to give a total number attributed to norovirus and rotavirus could be used to accurately estimate total hospitalizations for these viral infections. This approach may not take into account seasonal trends in testing practices or changes over time. Finally, only a few years of data were available for this study limiting the ability to assess any long-term trends in the number of infections.

Also of note, two rotavirus vaccines are approved and recommended for use in Canada; Rotarix ${ }^{\mathrm{TM}}$ was approved in 2008 and RotaTeq $^{\circledR}$ in 2006 [36]. However, only one province, with $0.4 \%$ of the Canadian population, had implemented a provincially funded vaccination initiative during the time-frame of this study (December 2010). It is unknown how many children were vaccinated during the study period, either through this provincially funded programme or through private purchases of vaccine. Since only a few years of data were analysed, and given the yearto-year variability observed, the effect of these vaccines could not be discerned. Analysis of hospitalization records beyond 2011 could provide insight into the effectiveness of the rotavirus vaccination programmes.

The total hospitalization costs were calculated based on the cost of a case with a most responsible diagnosis code of either norovirus or rotavirus, as a result the same cost was applied to community-acquired and nosocomial infections. Data limitations prevented the separation of costs for patients with a diagnosis of enteric viral infection post-admission. The underlying assumption of this approach was that the additional cost of an individual acquiring a virus in hospital is similar to the cost of an individual being hospitalized for an enteric viral infection. In addition, it should be noted that the cost estimates reported in this paper only reflect direct costs to hospitals and do not include costs associated with visits to physicians' offices, emergency rooms or other healthcare costs. Our estimates indicate that although rotavirus hospitalizations are more common, the total cost was higher for norovirus hospitalizations. This likely reflects the higher cost per hospitalization associated with the elderly which make up the majority of norovirus hospitalization cases in our database.
These estimates are the first comprehensive and age-specific assessment of norovirus and rotavirus hospitalizations in Canada. They provide data to understand the true scope of the burden associated with enteric viruses and can be used to assist public health decision-making.

\section{ACKNOWLEDGEMENTS}

The authors thank Dr Ben Lopman for his assistance with statistical methods, Mr Ken Eng for providing hospital cost data and Ms. Regan Murray for technical consultation.

Parts of this material are based on data and information compiled and provided by CIHI. However, the analyses, conclusions, opinions and statements expressed herein are those of the authors, and not necessarily those of CIHI.

This research received no specific grant from any funding agency, commercial or not-for-profit sectors.

\section{DECLARATION OF INTEREST}

None.

\section{REFERENCES}

1. Murray CJ, et al. Disability-adjusted life years (DALYs) for 291 diseases and injuries in 21 regions, 1990-2010: a systematic analysis for the Global Burden of Disease Study 2010. Lancet 2012; 380: 2197-2223.

2. Thomas MK, et al. Estimates of the burden of foodborne illness in Canada for 30 specified pathogens and unspecified agents, circa 2006. Foodborne Pathogens and Disease 2013; 10: 639-648.

3. Bettinger JA, et al. Heterogeneity of rotavirus testing and admitting practices for gastroenteritis among 12 tertiary care pediatric hospitals: implications for surveillance. Canadian Journal of Infectious Diseases and Medical Microbiology 2011; 22: 15-18.

4. Yen C, Hall AJ. Editorial Commentary: Challenges to estimating norovirus disease burden. Journal of the Pediatric Infectious Diseases Society 2013; 2: 61-62.

5. Glass RI, Parashar UD, Estes MK. Norovirus gastroenteritis. New England Journal of Medicine 2009; 361: 1776-1785.

6. CDC. Norovirus outbreaks on three college campuses California, Michigan, and Wisconsin, 2008. Morbidity and Mortality Weekly Report 2009; 58: 1095-1100.

7. Blanton LH, et al. Molecular and epidemiologic trends of caliciviruses associated with outbreaks of acute gastroenteritis in the United States, 2000-2004. Journal of Infectious Diseases 2006; 193: 413-421.

8. Bert F, et al. Norovirus Outbreaks on Commercial Cruise Ships: A Systematic Review and New Targets 
for the Public Health Agenda. Food and Environmental Virology 2014; 6: 67-74.

9. Said MA, Perl TM, Sears CL. Gastrointestinal flu: norovirus in health care and long-term care facilities. Clinical Infectious Diseases 2008; 47: 1202-1208.

10. Haustein T, et al. Hospital admissions due to norovirus in adult and elderly patients in England. Clinical Infectious Diseases 2009; 49: 1890-1892.

11. Mattner F, et al. Risk groups for clinical complications of norovirus infections: an outbreak investigation. Clinical Microbiology and Infection 2006; 12: 69-74.

12. Anderson EJ, Weber SG. Rotavirus infection in adults. Lancet Infectious Diseases 2004; 4: 91-99.

13. Bernstein DI. Rotavirus overview. Pediatric Infectious Disease Journal 2009; 28: S50-S53.

14. Parashar UD, et al. Rotavirus and severe childhood diarrhea. Emerging Infectious Diseases 2006; 12: 304 306.

15. Ruiz-Palacios GM, et al. Safety and efficacy of an attenuated vaccine against severe rotavirus gastroenteritis. New England Journal of Medicine 2006; 354: 11-22.

16. Wang FT, et al. Effectiveness of the pentavalent rotavirus vaccine in preventing gastroenteritis in the United States. Pediatrics 2010; 125: e208-13.

17. Lopman BA, et al. Increasing rates of gastroenteritis hospital discharges in US adults and the contribution of norovirus, 1996-2007. Clinical Infectious Diseases 2011; 52: 466-474.

18. Canadian Institute for Health Information. Hospital morbidity database, 2006-2010.

19. Statistics Canada, Demography Division, Demographic Estimates Section. October Population estimates, 2006-2010. Updated postcensal estimates, 2012.

20. Public Health Agency of Canada. National Enteric Surveillance Program, 2006-2011.

21. Public Health Agency of Canada. Economic burden of illness in Canada, 2005-2008. 2014.

22. Pang XL, et al. Influence of novel norovirus GII.4 variants on gastroenteritis outbreak dynamics in Alberta and the Northern Territories, Canada between 2000 and 2008. PLOS ONE 2010; 5.

23. Bernard S, et al. Burden of rotavirus disease: a population-based study in Eastern Townships, Quebec. Canadian Journal of Infectious Diseases and Medical Microbiology 2013; 24: 138-142.
24. Public Health Agency of Canada. National Enteric Surveillance Program (NESP) Annual Summary 2012. 2014.

25. Ryan MJ, et al. Hospital admissions attributable to rotavirus infection in England and Wales. Journal of Infectious Diseases 1996; 174 (Suppl. 1): S12-18.

26. Verhoef L, et $\boldsymbol{a l}$. The estimated disease burden of norovirus in the Netherlands. Epidemiology and Infection 2013; 141: 496-506.

27. Rivest $\mathbf{P}$, et al. Hospitalisations for gastroenteritis: the role of rotavirus. Vaccine 2004; 22: 2013-2017.

28. Payne DC, et al. Secular variation in United States rotavirus disease rates and serotypes: Implications for assessing the rotavirus vaccination program. Pediatric Infectious Disease Journal 2009; 28: 948-953.

29. Siebenga JJ, et al. Norovirus illness is a global problem: emergence and spread of norovirus GII.4 variants, 2001-2007. Journal of Infectious Diseases 2009; 200: $802-812$.

30. Tu ET, et al. Epidemics of gastroenteritis during 2006 were associated with the spread of norovirus GII.4 variants 2006a and 2006b. Clinical Infectious Diseases 2008; 46: 413-420.

31. Le Saux N, et al. Hospital acquired rotavirus infections: burden in Canadian paediatric hospitals. Journal of Infection Prevention 2011; 12: 159-162.

32. Bruijning-Verhagen $\mathbf{P}$, et al. Rotavirus-related hospitalizations are responsible for high seasonal peaks in allcause pediatric hospitalizations. Pediatric Infectious Disease Journal 2012; 31: e244-e249.

33. Wilhelmi I, Roman E, Sanchez-Fauquier A. Viruses causing gastroenteritis. Clinical Microbiology and Infection 2003; 9: 247-262.

34. Pang XL, Preiksaitis JK, Lee BE. Enhanced enteric virus detection in sporadic gastroenteritis using a multitarget real-time PCR panel: a one-year study. Journal of Medical Virology 2013; 86: 1594-1601.

35. Pang XL, et al. Epidemiology and genotype analysis of sapovirus associated with gastroenteritis outbreaks in Alberta, Canada: 2004-2007. Journal of Infectious Diseases 2009; 199: 547-551.

36. National Advisory Committee on Immunization. Updated statement on the use of rotavirus vaccines. Canada Communicable Disease Report July 2010, 36, ACS-4 (http://www.phac-aspc.gc.ca/publicat/ccdr-rmtc/ 10vol36/acs-4/index-eng.php). 